\title{
Contesting Secularism? A Case Study of Deobandi Women Madrasas in Iran
}

\author{
Hoshang Noraiee \\ London Metropolitan and the University of Westminster
}

\begin{abstract}
In response to the pressures inflicted by the processes of modernisation and globalisation, particularly the spread of secular education among women, the Sunni male religious authorities in Iranian Baluchistan, like many other places, adopted new strategies. They specifically and unprecedentedly introduced female institutions to control behaviour of young females. However, these measures have significantly affected the behaviour and image of women madrasa students and teachers about their social roles, which traditionally were restricted to the private sphere of familial institutions as were sanctified by the religion. In a complex process of social change, associated with the diversification of values, the madrasa women, in their own ways, defined their individuality, identity and rational judgements. This article investigates the changes in attitudes of the religious authorities regarding religious education of females; and examines the behaviour and images of madrasa women about their social roles in Iranian Baluchistan. In collecting data, the research is based on a variety of methods, both secondary and primary through different means of communication.
\end{abstract}

Key words: Deobandi, Sunni, Female Madrasa, Fazelah, Talibah, Baluchistan, Iran, Education,

\section{INTRODUCTION}

In a speech moulvi Mohammad Yousuf Husainpoor, the managing director of the Council for Coordination of Sunni madrasas (seminaries) in Sistan and Baluchistan (hereafter CCM), and director of the A'in ul-Ulum Madrasa- Gosht (The Source of Knowledge), has strongly attacked the teachers, educational authorities, and the policies which widen the space for women students in state Schools.

In the speech, he angrily announced his concerns regarding the lack of hijab, the issue of socialising and mixing of women and men, and the question of camping and school trips for women and men, even though they were held separately. He asserted that "the integrity, respect for life, is gradually moving away from us"; and "the girls without a close member of male family (mahram) gather and travel for leisure, sightseeing and camping. Is it an honour for you?" He added that "if this situation really continues, we have to shut down those schools, we don't want our daughters to be dishonoured" .... "We have forgotten the Quran and have pursued western type of development........ In the past, if someone got a bad reputation your decency would request to destroy her. You have become dishonoured, what decency do you have?"... "from when they are 6 years old, the girls in groups of 30-40 gather and talk with each other to overcome their sense of shame and honour..... We should find a solution for these problems.... I have really become mad, I have caught fire, I warn the teachers, the education authorities, if they continue in this way I will ready to lose my head in this case. We don't want this kind of education, to destroy our reputation, to be like American and male and female mix together". Then he said that "we loudly shout 'death to America' but we follow their ways." (A private audio which may be from 2009-2013, received 2016). 
This speech, which is full of threats and even encouragement of violence, was delivered quite recently by a traditional and influential moulvi, a long time after the construction of the female madrasas (maktabs), confirmed by CCM. The Sunni clerics and their affiliated websites widely argue that the notion of women's freedom is a "conspiracy" by the West (see Mahmoodzahi, 2016). The clerics in the area argue that it is the obligation of Muslims and women's madrasas to stop the damaging cultural invasion spread by satellites and other means (See Ismailzahi, 2014). These ideas reflect the continuous concerns that the clerics have about the process of secularisation and women's increasing scope of socialisation, which influence women's lives.

The Sharia-oriented institutions, particularly where they are strong, have always attempted to limit the power of modern secular institutions and individuals, to limit their influence on women's lives. The conservative Sunni clerics, in Sistan and Baluchistan, as many others in different places, have seen secularisation and rationalisation as real threats, and corrupting factors in Islamic society. By influencing women's lives, they believe, rationalism, particularly through secular or state education, has been undermining the core moral issues defined by the Islamic religion. The visibility of women in public places has been the most important source of fear for the conservative religious male authorities, believing that women in this way have been questioning the superiority and authority of males, and destabilising the traditional values.

In response, to minimise what they have considered as the damaging effects of this process, on an Islamic society in general, and women's behaviour in particular, the clerics adopted new and difficult strategies. Rather than sticking only to the inefficient and old mechanisms of preaching about controlling women in the domestic space, from the early 1990s, they started to build religious institutions, such as madrasas, missionary organisations and worshipping congregations, for them. These institutions have served as a new means of educational control by partially including women, in organisations which traditionally were exclusively preserved for the male.

In adopting such a strategy, in Iranian Baluchistan, the Sunni religious authorities were influenced by national, regional and global geopolitical transformation. The Iranian revolution, and the developments which emerged in Afghanistan and Pakistan, significantly reshaped the religious institutions in the whole region in general, and particularly the Deobandi madrasas' organisations. However, because of the constant pressure of the secular environment, and distrust of the IRI education system, the Sunni clerics have never felt comfortable about women challenging positions and new forms of socialisation in their communities.

Since then, an even bigger issue for the traditional clerics has been the spread of the internet and social media, which are widely used by females, particularly young women, for communications, exchange of ideas and personal relationships. Now we are going to look at some researches available on comparable women's madrasas in the region, particularly in India and Pakistan.

As far as I am aware, there is only limited empirical research on the Deobandi female madrasas. The existing researches cover some specific areas in different countries, particularly Pakistan and India. However, there is not even a single research on Deobandi female madrasas (or, for that matter, male) in Iran. Research on women's madrasas, in the subcontinent was neglected for a long time, but when the Jamia Hafza Madrasa revolt also known as the Lal Masjid (Red Mosque) event - happened in 2007 in Islamabad, the women's madrasas were subjected to further scrutiny, mainly to understand the possibility of radicalisation of these types of madrasa (see MEMRI, 2010; Roul, 2010; Ali, 2009; Jalil, 2005). 
The researches, conducted by Bano $(2010,2007)$ and Fair (2008), in Pakistan, explain the development of women's madrasas by applying demand side economics under uncertain economic conditions. Their focus has been predominantly on the urban middle class madrasas, with complementary and rational goals. But there are various types of women's madrasas in Pakistan, and only some of them, which work as private educational businesses, are subject to rational choice and are likely to be regulated by the government education department (e.g. see Jamia Minhaj ul- Sharia, 2010; also, Noraiee, 2011).

For some other researchers, the emergence of female madrasas has been considered as a defensive response to the modernisation of society and liberal attitudes towards women (Alam, 2010; Sikand, 2006; Winkelmann, 2005). However, these researches are based on madrasas in India; it is very likely that many madrasas in Pakistan have the same concerns and define their aims as transcendental.

With regard to explaining the influence of madrasas on female students in different cases, however, a number of researchers have made attempts to apply the Focauldian approach of body control or Goffman's “total institutions” (see Alam, 2010; Farooq, 2010; Mahmood, 2001, 2005; Winkelmann 2005; Lughud, 1998; and for a comprehensive revision sees Noraiee, 2011). From this perspective, the madrasas are considered as "total institutions" which strongly and physically control gender relations. A question which remains from here, and needs to be investigated further, is how strongly formal organisational regulations and mechanisms of controls can make women submissive.

In another study, Jeffery et al. $(2006,2004)$ explained the behaviour of religious authorities in India, on the basis of gender and class relations. They believed that religious authorities viewed madrasas and education from a modern middle class point of view. Based on this approach, it can be suggested that clerics do not have homogenous interests, and in relation to women they may adopt different strategies.

In exploring the madrasa women's behaviour, nearly all researchers have heavily focused on formal sources and curriculums and ignored the fact that women in madrasas are not a passive force, but they are active and able to manipulate the rules and regulations (see Scott, 2010). In these studies, broader political, economic and cultural reasons for the emergence and development of these madrasas have been underestimated.

In a broader context, despite all the pressures for Islamisation and de-secularisation of society by the conservative Muslim authorities, supported by the traditional familial institutions, rationalisation has not been completely prevented from progressing (see Ruthven, 2007). As has been argued by Riesebrodt (1993), what "fundamentalists" are not able to stop in structural transformation, they attempt to impose in symbolic ways (see Ruthven, 2007:65; Wood and Bunn, 2009; Brannen and Nilson, 2005; Veter, 2003; Beyer, 1990).

In the globalising era, the sense of power by agencies which have shaped women's identities also should be considered. The general concepts discussed by Giddens (1991) as selfreflexivity in the context of "de-traditionalisation", and by Bourdieu (1990) as practical strategies, could be illuminating. In the same way, Bauman (2007) in "Liquid Times" and Beck (1990) as risk society, have explained some significant aspects of globalising societies. These characters of western societies may not spread evenly and smoothly, but have touched nerves everywhere. 
This article will show that how the progress of the contradictory aspects of "detraditionalisation" (Heelas 1996) ${ }^{1}$, in Islamic traditional societies, is reflected in the manner of the religious male authorities towards women, particularly due to the emergence of female Islamic madrasas. This study also examines the madrasa women's behaviour, in the contexts of the madrasas and other religious institutions. In this respect both opportunities and constraints, in shaping women's identities will be discussed.

\section{METHODOLOGY}

This study is based on both primary and secondary data, collected during a period from 20082016. Some sections of it were presented at a conference on globalisation at the Cocaily University in Turkey in 2010. The primary enquiries were made through personal contacts, interviews, informal conversations, and written answers to some open and semi-structured questionnaires. These measures were implemented by means of emails, telephone calls, post and fax, a few face to face interviews, WhatsApp and other forms of social media. A wide range of secondary data was acquired by looking at the websites and newsletters to which I had access. The documents are mainly available in the Persian language.

Access to women as madrasa students or teachers is not impossible for a male researcher, but it is extremely difficult. I was able, through my family connections, to have access to some of the women informants and a few male clerics who teach and work at madrasas. The range of participants was widened to some extent by getting written responses to the open/ semistructured questionnaire. In this respect, I was also helped by the same family members. For many reasons, I should keep their names anonymous and only use pseudonyms.

As far as the responses to the questionnaires is concerned: the number of respondents was 27, of whom 24 were talibahs (female madrasa students) and 3 were moddaress (teachers). The respondents were from two madrasas, and some of them had experience of studying in both places. Both madrasas are located in Saravan district in Southeast Iran in the province of Sistan and Baluchistan. Nearly all female students and teachers who participated in the research were from the same or adjacent local areas.

Face to face informal conversations with three women, including two fazelahs, one talibah, and one male moulvi, were conducted in a Gulf country in August 2015. Three of these participants had already helped me in collecting information as well. Since then, data gathering has been followed up through Viber and WhatsApp chats and text messages.

Geographically, the empirical research gathered from interviews is mainly limited to Saravan district, where I had more opportunity to find and contact people. The number of participants is also limited and gaining access to more women participants was extremely difficult. Meanwhile, there may be some differences between behaviour in madrasas and the way women behave in different social, political and cultural settings. These make drawing general conclusions very problematic. But it is also very likely that in many respects there are some similarities; for example, the teaching programmes, background of the teachers, general religious and cultural concerns and male decision makers.

\footnotetext{
1 -According to Heelas “As a working definition, de-traditionalisation involves a shift of authority from 'without' to 'within'. It entails the decline of the belief in pre-given or natural orders of things. Individual subjects are themselves called upon to exercise authority in the face of the disorder and contingency, which are thereby generated. 'Voice' is displaced from established sources, coming to rest with the self." (Heelas, 1996:2).
} 


\section{FINDINGS AND DISCUSSIONS}

Now we will outline and explain the findings under the following subsections: I) a general view of female madrasas; II) Personal identities of the fazelahs and talibahs; III) Local labour market, opportunities and constraints; IV) Acquisition of knowledge as a choice through madrasas; V) Talibahs' and fazelahs' images of self and male authorities; VI) Corruption as a main concern; VII) Challenges: family and society; VIII) Piety and confidence.

\section{A general view of the female madrasas}

Opening female madrasas among the Sunni Muslims in Southeast Iran is a new phenomenon. Before the Islamic Revolution in 1979, there were no women madrasas in the area and the moulvis (a title for highly-ranked and qualified Sunni clerics in the area,), were even strongly against women's education in secular institutions. After the revolution, the moulvis, for about a decade, became more relaxed about the Islamic State's policies because they felt that the new regime would widen their control over the public sphere. Thus, they adopted a softer approach regarding women's education. Influenced by the developments in Iran and among Deobandis in Pakistan, they started to open female madrasas in the early 1990s.

However, the female madrasas started to emerge quite recently; in 2011 one moulvi stated in an interview that "the girls are doing very well and the number of their madrasas soon may exceed the male madrasas" (SH, 5 September 2011). Now (2016), it is estimated that the number of women's madrasas has already exceeded the number of male madrasas.

According to another moulvi (AH, 12 December 2016) there were more than 50 female madrasas in the town of Saravan alone in 2016. Eshaa't al-Towhid Madrasa-Saravan stated that they had 30 female affiliate madrasas in Saravan in 2013 (Eshaa't al-Towhid, 2013). Dar-ulUlum Madrasa-Zahedan (House of Knowledge Madrasa), also known as Makki Madrasa, opened its own female madrasa "Maktab-e Hazrat A'isha Sediqah" ("Madrasa of Saint Aisha"), in 1991. This female madrasa, which is the largest, and possibly the only one with board and lodging facilities, in the whole province, has 12 branches in Zahedan (Sunni online, 2017). Considering the overall evidence, the total number of female madrasas, big and small, can be estimated to be considerably higher than 500 , with over 10,000 talibahs.

All women madrasas, in terms of catchment areas, are highly localised, while the bigger male madrasas are provincial or even regional. Because of the restraints imposed on the mobility of women, as a matter of prestige, reputation, accessibility and publicity, many smaller women madrasas or maktabs have been locally established. They have been spreading in local areas to provide the community women with religious education. Simultaneously, it seems that localisation of women madrasas is used as a mechanism of surveillance for judging women's behaviour, and putting pressure on them to comply with religious values and act according to the male projected programmes. The number of talibahs in each female madrasa varies, but on average may be between 20-30 and the larger maktabs could have 50-60 talibahs, while the biggest madrasas which are directly managed by big male madrasas have over 100 talibahs (Mory, 9 December 2016). (See Appendix-1; Table-1)

The local maktabs, as affiliates of more prestigious male madrasas, have in some cases been sponsored by wealthy local business people (mainly male). These types of madrasas usually use volunteer fazelahs in teaching basic courses, and moulvis from the established male madrasas for teaching more advanced courses. 
Unlike the male teachers, nearly all women teachers are unpaid. For example, among all women madrasas in Saravan, only about 2 women madrasas pay wages to fazelahs, mainly on a part-time basis, and at a considerably lower rate than male moulvis. Unpaid women teachers may be rewarded from time to time with gifts from students and sometimes officials and donors. Mory, a female part-time teacher, put it in this way "It does not mean that we get nothing. I myself want to get my wage in another world and get it in full and few times more." (10 December 2016).

There is not a clear figure for the number of annual graduates from the female madrasas in this province, but currently it may easily be 400-500 for the whole province. Many smaller madrasas are not at a level to have their own graduates, or they are new, and some of their talibahs join other local maktabs for higher level studies. These figures do not include the number of hafizes (memorisers of the Quran by heart), who annually can be a few hundred in the Province. Only in 2017, Dar ul-Ulum in Zahedan celebrated the graduation of 136 fazelahs (Eshaa't al-Towhid, 2017). For 3 years, from 2013-2016, a few Maktabs affiliated to Shams ulUlum and Dar ul-Ulum Haqqaniyya in Iranshahr had 184 women graduates (see Shams online, 2016).

According to an estimate for Saravan town and surroundings only, in 2015 in total there were about 2,000 fazelahs but only about 100-200 of them were engaged in teaching at women's maktabs (Mory, 24 April 2016). Others work as housewives, and many of them at the same time teach the Quran to neighbouring women and children at home. Some of them are also active in participating and organising Tablighi Jamaa't groups for women.

Female madrasas, as far as they are affiliates of CCM male madrasas, follow a male- catered, quite standardised curriculum, which is a diluted version of the male one, set by the $\mathrm{CCM}^{2}$ (see Appendix- 2; Table- 2). Therefore, the female madrasas are regulated and controlled by the male madrasas. In terms of opportunities for higher levels of education and more specialised choices, the female students are more limited and less privileged, in comparison to the male students. However, in some areas they have gained some opportunities to study at higher levels particularly in Zahedan. For example, in "Maktab-e A'isha Sediqah", the women can be specialists in the areas of Tafsir, Jurisprudence, and Guidance and Islamic Thought (Sunni online, 2017).

Because of the nature of female madrasas as local institutions, and the dominant attitudes of family and male authorities, nearly all female madrasas do not benefit from the full board and lodging facilities made available for full-time male students in many large madrasas. Meanwhile, male students' studies last for a period of 9 years (or in some cases as much as 10 or even 12 years) while female students' studies take 7 years. For the first 3 years, they mainly study grammar, basic subjects in ethics and Fiqh, mostly in the Farsi language, but after that they gradually start to study some more complex and ancient texts in Fiqh, Tafsir and Hadith, mainly translated into Farsi and some into Arabic as well (See Appendix- 2; Table- 2).

Furthermore, the male students can move to other non-local and more prestigious madrasas, both in the same province and even in Pakistan, where they can continue their studies in more

\footnotetext{
2 The curriculum approved by the CCM is based on the curricula of a selection of Deobandi madares (pl. madrasa) in Pakistan but it is not the same (see Farooq, 2010: 80-83). For another curriculum and the Dars-e Nizami curriculum see Fair (2008: 103-114). The main text books in the curriculum are old and hardly include any books from $19^{\text {th }}$ century and after. Hadith, as the main specialised area, has a special place in the curriculum of male madrasas, but is less focused in female madrasas.
} 
specialist areas such as "Efta" (religious edicts) and Hadith (tradition). But the full-time women have very limited chances to move to a prestigious madrasa and gain specialised titles as men do.

With the increasing number of fazelahs in this province, some fundamental changes can be seen in the local communities. For the first time, many women attend large public assemblies and large social congregations, although physically separated from the males. For example, about 3 decades ago, there were no women's Tablighi Jamaa't groups in the area, and they never attended Tablighi Jamaa't or any other collective prayers at mosques. But nowadays they organise their own Tablighi Jamaa't in the local area and even perform prayer in mosques, in an area segregated by a curtain or wall from male areas.

At the same time, the commitment to hijab has been considerably increased. About 3-4 decades ago, there were hardly any women wearing niqab or burqa in public, but nowadays there are many. For example, at that time, in a very well-known religious village, there were fewer than 5 women who were seen sadri (satri or setri) and they were usually secluded in their home rather than using a full covering veil and going out, but now there are possibly 40-50 times more satris, including all female madrasa students, who are very likely to wear the burqa and go out to participate in local women-related congregations and institutions.

\section{Personal identities of the fazelahs and talibahs}

The population structure of respondents in terms of age, state (secular) educational background $^{3}$, marital status and occupation provides us with some evidence regarding the personal identities of the Talibahs, the motives they have and if there is any connection between their current religious education and their state schooling.

The female respondents, including 3 young female teachers, were between 18 and 36 years of age. While $18(67 \%)$ of them were 25 or under, only $3(11 \%)$ of them were over 30 . This means that the respondents were mostly from a generation born after the Iranian Revolution in 1979. In reference to the marital status, 10 (37\%) of them were single and between 18 to 25 years of age. The percentage of single women attending local madrasas were significantly higher, as traditionally single women, after the age of puberty, were more restricted and were not allowed to leave home. About $63 \%$ of the women who responded were married, which indicates that marriage did not seem to be a major barrier to attending the local madrasas.

The students' marital status indicated that the attitudes of familial institutions had changed and also that daughters or wives had gained more power to negotiate and improve their positions - both in the families and in the communities. The significant number of married talibahs in madrasas also showed that women had gained more space to pursue some of their ambitions outside the home and, at the same time, improve the status of their own family, as pious and educated, in the community. On the other hand, there are some cases in which families put pressure on women to go to madrasas rather than giving them an opportunity to choose.

\footnotetext{
${ }^{3}$ In an Islamic state, for example Iran, where there is no boundary between Religion and the State, it may be better to use the concept of state education rather than secular education because, to a large extent, the state regulates the system of education based on its religious-political ideology.
} 
Considering the age of the students, nearly all of them had state education under the Islamic Republic of Iran, during which many local girls' schools became available. At that time, about $50 \%$ of the talibahs had a diploma (12 years of state education) and nearly $75 \%$ of them had a diploma or a secondary level qualification (between 9-12 years of education). The other $25 \%$ were educated up to primary school level only (up to 6 years of education). Eighty percent of the single female students had diploma qualifications compared with $47 \%$ of the married women. But now it seems that, particularly in smaller maktabs which are less prestigious than the women's madrasas attached to larger male madrasas, the number of diplomas has become considerably less. For example, in a maktab in Saravan (February 2016), in grade 2, from 9 talibahs only 3 had diplomas. There are hardly any university graduates among the talibahs. Meanwhile, during the last decade, from the time the semi-structured questionnaire was conducted, opportunities for diploma-holders to enter universities have considerably increased, and these are available in all small districts, and through correspondence nearly everywhere.

\section{The local labour market: opportunities and constraints}

Occasionally, for educated women with diplomas or higher qualifications, some teaching jobs or other forms of employment may be available in local schools and health centres, but their families may restrict them from accepting such kind of jobs which require daily commuting to schools and much engagement and commitment outside the home.

However, this is not always the case; for example, a moulvi had told his daughters there would be no problem with them working if they could get jobs locally but they would not be allowed to move to another place. Another male moulvi, with a university degree and a teaching job in a madrasa, has allowed his wife, who has a university degree as well, to attend a local female madrasa to study, and also to work as a full-time/part-time in a social caring institution in the district centre.

But generally speaking, and as the research findings about the female respondents in the rural area and small semi-rural town showed, the local labour market provided very limited opportunities for employment. For example, none of the talibahs interviewed had a paid job and 3 madrasa teachers were working as volunteers.

To gain more insights about the labour market restraints, it may be useful to notice that among the husbands of the married women, 9 out of 17 (53\%) had a diploma, but only a few of them were in teaching professions. One of these men, mentioned in the questionnaire, had a degree and also worked as a teacher. Many of the husbands had been categorised as self-employed or their jobs were left unspecified. Self-employment in the local area is more likely to be an involvement in the informal economy, which is mainly based on small-scale trading, or even a form of unemployment with seasonal or casual work. This is evidence that a large number of the madrasa married women were from the families with insecure jobs.

But the constraints on choices beyond madrasas, such as early marriage and the restriction of mobility of females, are still strong and act as a disabling force, combined with the constraints in the local labour market in terms of limited employment opportunities. Where the actual choices are limited, the experience of these women in secular education seems to have an important influence on their process of making decisions to join the local madrasas. It seems that the same process for gaining social and cultural capital has been extended to the religious fields. 
The restrictions on mobility act not only with regards to the employment of women, but also to the continuation of their secular education, particularly at the higher levels. Studying at the higher and more prestigious educational institutes, which are mainly established in the larger cities and towns, not only requires passing an entrance exam but also extra financial resources. Furthermore, the willingness of the families is crucial, to overcome the conservative community traditions by allowing their daughters or sisters to move to another place further away from their families.

These constraints may also reflect the girls' own preference to study at a local madrasa rather than in secular higher education. Among the respondents, only one student wished that she could continue her education at the university, while all the others preferred to study at a religious madrasa of their preference. However, this may not reflect their real wishes as a teacher believed that many of the students had not much motivation to study at madrasas, but they had no other opportunities to continue their studies at universities. Now the reason for a decrease in the number of female diploma-holders in madrasas could be related to an increase in opportunities in higher education (Mory, 4 January 2017).

This illustrates that the respondents' statements in this regard should be interpreted with great caution because they express their ideas within a context in which their choices are actually limited. Besides, they had already been engaged in a madrasa education which had attempted to instil a sense of the superiority of this choice in an absolute way. Meanwhile, in contrast to the existence of women madrasas with full board and lodging facilities in Pakistan, in Iran, so far, the female Deobandi madrasas rarely have had such institutions.

\section{Acquisition of knowledge through madrasas}

Desire to acquire knowledge has been mentioned as the most important aim in the students' statements. It should be noticed that for the madrasas knowledge is very much limited to religious understanding. The evidence suggests that, apart from some basic linguistic subjects, they had hardly read books or other materials apart from religious text books which are prescribed by madrasas and are seen as comprehensive sources of "knowledge". But considering the wide range of communication facilities available to them, locality, the madrasa organisation, and textbooks are no longer determining factors to exclusively structure the behaviour of women, men and communities.

Nearly all the respondents wanted to understand or become familiar with Islamic rules, the life of the Prophet Mohammad and his companions, and in fewer cases, they also want to understand the problems women face and the position they should occupy in Islamic societies.

One talibah has listed her aims as follows: "reforming oneself and the society; understanding our own religion; receiving God's blessings; being close to God; and wishing to invite and convert an infidel to Islam". These aims in many ways are general, but traditionally were considered as a field for the male, rather than a female who also wishes to undertake evangelical missions.

Many them said they would like to become a madrasa teacher after completing their studies. Some had evangelical purposes and declared that they would like to become a preacher, and to spread Islamic views. In a telephone conversation one talibah told me that she had a diploma, 
but she also needed to look after her children and there were many educated people in secular subjects, but there were not many educated in religion (Mory, 10 September 2008). ${ }^{4}$

The talibahs' secular educational background, possibly influences their desire to appreciate institutional, systematic and authority-based achievements in the religious field. Many diploma-holders and those with State school experience also feel that the female maktabs are not serious. Mory (24 April 2016) said "when someone comes from the state schools, she feels that the maktabs are not well disciplined and they are not at the same level with others but soon they get used to". The students' interests, in some cases, can also be interpreted as a desire for self-fulfilment in the context of existing constraints within the community.

For many ambitious women, progress through other avenues seems to be very limited or nearly impossible in the communities they live in, so the only route available to them is through the locally based madrasa education. The pressure of traditions limits women's actual choices, but by attending the madrasas they gain opportunities to socialise outside the traditional settings of their homes and families. This is an indication or outcome of the process of "de-traditionalisation" in rural and semi-rural communities in that area.

For the talibah, acquiring knowledge through traditional sources, such as familial and tribal institutions, is obviously neither credible nor desirable anymore. The questions they try to answer and the research they want to be involved in are not the continuation of traditional values which should be taken for granted. They do not consider their acts as destiny, but perceive them as choices and the results of their own exploration in that particular context. In this respect, a secular institutional source of socialisation is transmitted to the religious institutions. This line of action by the students reduces the pressure of the local constraints and enables them to find opportunities for further (but indirect) movement towards and in the public sphere. This occurs through engagement in women's networks organised by the Tablighi Jamaa't or other types of women's congregations.

Passion for exploring and acquiring knowledge among the women, particularly younger generations, in those communities is, to a great extent, inconsistent with the traditional demands of "passivity", to silence women and encourage them to restrict themselves to being good housewives at home. Manipulation of traditional values, even through existing familial and religious institutions which impose some restrictions on their behaviour, are not uncommon for younger women.

The madrasa education appears in sequential terms as a complementary process to secular education, as Bano $(2010,2007)$ has suggested; but it is neither a simple continuation of the modern secular education, nor a clear break from it. In spite of Bano's findings in Pakistan urban areas, on the basis of the data we gathered in this area there is no explicit purpose of economic gain, or their economic aims were simply overshadowed at that stage by the search for higher self-esteem and prestige. Psychologically, this might have been more desirable for both the parents and the students when it comes to gaining respect and improving their prestige in the community. However, in reality, they have neither benefited from economic gains, nor achieved unchallenged status in society.

\footnotetext{
${ }^{4}$ Now Mory, after about 10 years, has become a fazelah and teaches at a maktab. Compared with her early optimism and enthusiasm, now a degree of illusion is seen in her opinions.
} 


\section{Talibahs' and fazelahs' self-image and male authorities}

Talibahs' motivations for attending a madrasa are various so the images they presented of themselves are also can very different from each other's. Mory (4 January 2017) suggested that:

In the seminaries, there are a few different types of talibahs, some enter with previous interest, some have nothing to do and choose it as a fun. Some of them come because of being unsuccessful in entering Universities. However, this group has become less because of the availability of further universities and easier conditions for entering higher education. There is another group who enter because of families persisting manner. But only those talibahs will stay and continue their studies at madrasas who are interested in pursuing transcendental ends. This group does this because they are not in search of increasing their opportunities in the labour market, as in this field, there is no, or just a very little opportunity to get a job and earn an income. There are also some talibahs who pursue name and fame and they like to be admired as alemah. Considering all these problems, in my opinion, only those can stay and complete their education, who are divinely devoted from the beginning, or they are able to change their this- worldly aims, in the process of studying.

Have the conservative clerics been able to encapsulate these women with such a wide range of aims, to be obedient?

A degree of confidence is evident in the manner of the talibahs, who eagerly compare and judge their own roles and talents with men, though this confidence is not embedded in madrasas as projected by the male authorities to train submissive women. A talibah who believed that men and women are equally talented stated:

Women and men should not have equal rights. Men have more rights than women, as it has been said in the Quran that "men are superior to women". Men will always be superior to women, and they will have more rights as the Prophet, peace upon him, has said: "if - apart from God - there was no one else to be worshipped, I would order women to worship their husbands."

Nearly all of the respondents believe that the superiority of men is an Islamic value and many of them had supported their ideas with a Quaranic verse: "ar-rejalo qawammuna al-nesa", which literally means "men are superior to women". However, in many cases the same women clearly and strongly believed that women are as talented as men, and some of them even suggested that some women are more talented than men (for similar cases in India, see Jeffery et al. 2006). However, when it comes to women's roles, rights and statuses they become divided.

A talibah with more balanced views believed that while in some areas women are more talented than men, there are some areas in which men are more talented than women, so, both male and female have equal rights. But at the same time, she also believed that:

As it has come in Hadith, women are inferior to men in reasoning and religion, but history has shown that many women have reached high levels of scientific achievements and they have fought on battlefields as men have done, and possibly, one day will come when Muslim women will occupy top leadership positions in their countries.

They also found themselves in a position to evaluate totalities such as the state and power relations, but at the same time they had been guided by ideologies dominant in madrasas and 
sanctioned by local communities, and national and local media. The ideas spread were predominantly uncritical, prejudicial and very often full of conspiracy theories.

Even though their judgments were significantly biased and to a large extent were based on madrasas teachings, these women's political opinions on different countries clearly reflected their concerns about global issues. Particularism imposed by Islamic religious communities, was widely associated with conspiracy theory, both in a broader and narrower sense. They had not learned to remove strict religious boundaries, so their judgments were ready-made for blaming "outsiders" for all sorts of evils in the Islamic societies.

At the same time, they had extended their particularism to go beyond a sense of nationality, geographical and ethnic and linguistic divisions to include the Sunni Muslim community (Ummah) as a whole. For them, as they were taught cultural superiority of Islam over all other religions, their ideas were not subjected to negotiation and enlightening dialogues.

When it comes to figures as role models, they hardly see anyone beyond the local or national male figures. In terms of gaining political power, they seemed cautious and showed little desire to let the domestic and educational role of women be overshadowed by any political role.

While they had admired a traditional family role, they had redefined domestic duties. The traditional domestic role, in this context, was redefined as a new role: "a domestic power", to relate to their knowledge and status. As a talibah stated:

In my opinion, the Almighty God has created a woman for rearing children. Women should be caring for their families which make up society. Women should bring up their children properly so that they become more useful rather than harmful individuals to the society. And in this way women help their society and country better than a leader.

At the same time, many madrasa women had redefined their role beyond traditional domestic duties, for example, taking responsibility for reforming society and accepting evangelical missions to convert non-Muslims to Islam.

\section{"Corruption" as a main concern}

The existence and spreading of "corruption" in society is possibly the most popular buzzword heard from the religious communities including madrasa women. They saw corruption in: the lack of piety, not wearing hijab at all or in a proper way, irreligiosity, immorality, adultery, and socialising and chatting of young females with young males.

Roza (11 September 2015), a married woman, who started her part-time madrasa study, nine years ago and expected to finish it a year later, believed that, despite having a university degree in theology, she had not been successful in finding a good job in the public sector. She was hopeful that she would be useful in terms of helping others to know about religious duties such as praying and fasting and also help them to avoid falling into corruption which she considered to be the main source of the problem in the western countries.

Roza believes that non- Islamic cultures like Christian and European are inconsistent with Islamic Sharia, in the sense that in their culture "women and men are mixed and they have no commitment to hijab. The foreign cultures cause bad-hijab or hijabless among women and cause many other abnormalities for both men and females, particularly for those with weak faith" (Roza, 11 September 2015). Many of the earlier respondents also had regarded the US, Israel and the UK as the worst countries in the world. 
The participants had no clear ideas about the countries which should be considered as uncorrupted sources of inspiration. A considerable number of them mentioned Arabic countries, and particularly Palestine, as their favourites. Only a few of them saw Saudi Arabia, Iraq or Iran as the best countries. Afghanistan and Pakistan were also mentioned as the best, but by fewer respondents.

Nevertheless, most of the respondents believed that an Islamic state is necessary in order to enforce Sharia law to eradicate corruption and bring about justice. They believe that the Islamic state is needed to bring Islam to its glorious time of the Prophet and caliphs who had the power to conquer the two greatest empires of the time, Iran and Rome.

\section{Challenges: family and society}

Living in community, the madrasa women faced various challenges. Both fazelahs and talibah may often be ignored, teased or not taken seriously by male family members or older women; for example, when a married talibah had tried to remind her grandmother about Islamic rules her grandmother had told her "shut up". When a madrasa graduate, and now a teacher, had covered herself in front of her male cousin, her aunt had called her by her belittling name to remove her veil in front of her male cousin (MH, 17 September 2010). A married man said "mentally, I prefer to ask religious problems from male clerics, I trust men more than women. At the same time, it is difficult for men to have direct contact with non-family women." (AB, 18 July 2010).

Clash of expectations of males and females is something which can be seen in the relation between husbands and married fazelahs. The husbands expect that because of their Islamic knowledge, as instructed by Islam, their fazelah wives should be more obedient, while fazelahs expect that their male husbands should understand their new role, rights and status. It seems that in many families this has increased the tensions between husbands and fazelah wives.

In the new context of clashes of status between husbands and fazelahs'/ talibahs' wives, the husbands, and the husbands' families, are seen as important factors in pushing married women to quit madrasa or divorce. Nik (11 July 2015) in a face to face conversation told me that her husband, who was regarded as a respectful religious figure by the local community, was "cruel" and "a bloody liar", did not respect her and did not allow her to teach or attend madrasa, and put pressure on her to stay always with him, do domestic work and accompany him whenever he wanted. This pressure led to divorce and Nik said that later her ex-husband sent a message asking her to remarry him, but she had rejected it and sent messages to him to "get lost". Such incidents could not be inspiring for many madrasa women who expected to gain more respect as alemah (fazelah).

In conversation with another fazelah, (Mory, 11 July 2015) told me that she enjoyed socialisation with her classmate and had the opportunity to exchange ideas on all issues including intimate matters. But the expectations of husbands and their families that women should do all domestic work and breeding put enormous pressure on her.

This situation led to disappointment and depression and she could hardly continue her madrasa studies for a while. As a result of this depression, she was looking for different alternatives to treat herself, but did not take sufficient notice of the fact that she was already in conflict at home with her husband who was her cousin. She told me that conflicts were the source of depression. 
Possibly, the lack of success in fulfilling expectations, such as social prestige and to some extent economic gains, as experienced some years later, might have disappointed the local women and some of their families.

However, while the number of women's madrasas has dramatically increased, the number of graduates has become fewer. For example, while the number of women students slightly increased in the "Village Madrasa", the biggest and most prestigious women's madrasa in the area, the number of women graduates consistently declined from about 30 in 2001 to 9 in 2016-2017, after a gradual improvement from 3 in 2010 (See Appendix- 3; Table- 3 and Figure- 1).

The drop out indicates that the students' interest in completing the course and obtaining religious qualifications is diminishing, therefore, the dropout rate from the "Village Madrasa" has been increasing 5 . A female teacher in this madrasa said:

The reasons behind this decline are spread of corruption, lack of consent and intervention of husbands/ masters and also heavy domestic duties of housewives. Most girls want to go to state schools and universities to get jobs and make money. (Nik, 19 July 2011, 24 July 2011).

For some similar reasons, many other local women start to attend madrasas but drop out in earlier stages of their studies, and thus only few are left to complete their madrasa studies (Mory, 11 July 2015). For example, at a maktab in Saravan, which was established in about 2002, there were about 25 talibahs in the educational year of 2015-2016. This maktab only kept classes open when there was a minimum of 4 talibahs. So, in 2015-2016, there were no $3^{\text {rd }}, 6^{\text {th }}$ or $7^{\text {th }}$ grades (the final year) because of drop out.

Mory also believed that madrasas were not very popular because over there, "there is no name, no job and no income", and many women leave madrasa to go to secular education and preferred this worldly life to other worldly rewards (4 January 2017).

\section{Piety and confidence}

While the madrasa women, even in a madrasa framework, have become more confident and more aware of their status, and expect men to respect them, and even attend women's meetings and go to mosque, they have become more hijabi, in terms of dress code. Competing with men in the area of religious piety also may be interpreted as a form of confidence and a challenge against the traditionally male monopolistic and excluding role. Hijab, is at the same time is used against less hijabi women, particularly with higher education backgrounds.

Women, as fazelahs, or talibahs, find themselves in competition with male authorities who enjoy far more freedom and respect, both in private and public spheres. This was possibly a reason that many women fazelahs and talibahs, from closed and semi-closed environments (including total institutions), compared with men, put more emphasis on their piety and hijab, and even sometimes show less tolerance towards what they see as corruption and nonreligious behaviour. In performing the religious duties, religious women even may be more persistent than the males.

\footnotetext{
${ }^{5}$ Another reason for less enthusiasm for gaining qualifications may be related to the Government policies which have not formally recognised CCM Sunni madras qualifications in the Province.
} 
For example, I noticed, in 2015, in United Arab Emirates, in a shopping mall, that the women were rushing to the mosques to perform praying, while a male cleric was more relaxed and believed that missing prayers in certain conditions was acceptable. The women may consider their strictness as a mechanism for building their identity to challenge a patriarchal environment.

Mory said:

In my view fazelahs become more aware of their rights in an Islamic framework and become more confident about asking for their rights; and their husbands, when see that women are reasonable, as far as possible, they accept. Certainly, women have become more confident and mutual respect increase [this]... does not mean that fazelahs become more obedient, if they see that their husbands are not prepared to accept their wives' rights, then the women choose to divorce. (25 April 2016).

Using the concept of "divorce", which was unimaginable in traditional and religious communities, has become quite normal for fazelahs. It means they do not fear of talking about "rights" and using modern and individual based solutions to achieve them.

In these cases, it seems that women shape their identity against "others", by redefining their piety as hijabis (owners of hijab). In their new positions as fazelahs and talibahs they have redefined the traditional values as their own possessions, something that they have acquired by their own efforts, not values to be simply inherited from the past. They gained these values, not through families and informal institutions, but through independent and formal institutions, madrasas, and obtained qualifications from there.

At the same time, this condition limits women's ability to question the nature of existing authorities. This is the disabling aspect of the religious education in madrasas, which suppress any critical approach and movement for further pluralism.

\section{CONCLUSION}

In the context of geopolitical transformations at global and regional levels, and in response to the ideological pressures by the Iranian Shia regime, the Sunni Deobandi moulvis started to open women's madrasas in South East Iran, Sistan and Baluchistan in the 1990s.

The development of these madrasas, in this social setting, was not merely a response to the rational needs of the market, but ideological, gender and ethno-religious issues were also involved. This was in reality a complex and a Janus-faced process, full of push and pull challenges posed by modern society in modern times, and it simultaneously contained inclusion and exclusion of women.

Women were included in terms of gaining a further opportunity to enter a field which was previously monopolised by the male authorities, moulvis. However, the male authorities adopted a strategy, beyond the traditional familial institutions, of including women, through planned organisational control, mainly in semi closed forms of madrasas, without lodging and boarding facilities. Simultaneously, there was a process of exclusion of women through being "curtained off", pressured to wear hijabs, and studying shorter courses.

While the processes of control and further disciplinary measures have internalised a particular form of an Islamic womanhood, they have not abolished agency, but increased the capacity of women to act as individuals. This has been a process of "de-traditionalisation", in a sense of 
breaking away from traditions and increasing individuals' capacity to realise their own "interests against the weight of customs, tradition, transcendental will (...) even if unintentional” (Mahmood, quoted in Winkelmann, 2005: 99).

Considering the evidence, Goffman's concept of "total institution" and the Focauldian approach of body control may not be sufficient to explain the issue. The intentions and expectations of the students as an active force should not be underestimated. These students and graduates are able to manipulate the regimented education system and move beyond the institutional intentions and the established rules. The individualistic values which have shaped women's identities further developed through the intra-institutional setting (see Scott, 2010; Yunus, 1994).

In competing with men, they have tried to redefine certain traditions and their domestic role as their own possessions, acquired through their own efforts and enquiries. They have interpreted piety and hijab as their identity. The evidence also indicates that the expectations women had to achieve, through the madrasa route, have not been properly fulfilled. Thus, the earlier enthusiasm of the women for studying and graduating in madrasa has relatively declined, although the total number of women's madrasas and talibahs in the province has dramatically increased. This is another form of resistance, by women, against the projected forms of control.

To put these changes in a wider context, it can be concluded that the process of change has been associated with creating opportunities and enabling forces for discovering and spreading of women's rational authority and to some extent weakening the authority of traditions. In other words, this has been a complex procedure, but has been associated with a process of rationalisation and individualisation, a basis for understanding the important role of the agency.

The evidence suggests, however, that even in the most traditional communities, individualisation and the building of identity by women have been spreading in different ways and social settings such as religious madrasas. Individualisation and self-confidence of the women in religious communities may intensify the clash of expectations between male and fazelah.

As a means of a stronger emphasis on their identity in the context of competitions with male authorities, who represent themselves as real and pious Muslims, and also with less hijabi women, madrasa women may be further radicalised. If the current tensions, which are based on highly biased and conflict-laden religious ideologies, continue in the whole region, the number of fazelahs among the Sunnis in southeast Iran may increase. Under such circumstances, it is also likely that for some time, madrasa women will strongly contribute to deepening the level of religiosity, and spread strict Sharia-based rules, associated with even further emphasis on totalitarian values. However, there are increasing counter-approaches coming from the women graduates of the state schools and universities who push for gaining more opportunities and direct engagement in the public sphere, arguing that individual choice and tolerance are not sufficient to counter the totality of societal or religious goods, which easily can support and legitimise violence. 


\section{Appendix- 1}

\section{APPENDICES}

Table- 1: Woman's Maktab-KL in Saravan in1916 (Mory, 10 December 2016)

\begin{tabular}{|l|l|}
\hline Foundation date & 2007 (1385hs) \\
\hline $\begin{array}{l}\text { The current Number of } \\
\text { talibahs }\end{array}$ & 30 , plus 20 in Rukhani (reading Quran) \\
\hline Teachers & 11 females, and 2 males who teach at higher levels (final years) \\
\hline Hafiz talibah & Initially no, later had but without success \\
\hline Wage & No wage, may get some presents when there is a graduation celebration \\
\hline Development & $\begin{array}{l}\text { Originally was opened as women's madrasa but also opened a men's } \\
\text { section with full lodging and board facilities and now has about 50 male } \\
\text { students }\end{array}$ \\
\hline Language, Exam & Teaching in Baluchi and Farsi, exams are in Farsi \\
\hline
\end{tabular}




\section{Appendix- 2}

\begin{tabular}{|c|c|}
\hline Year & Textbooks (Date of death) \\
\hline Year 1 & 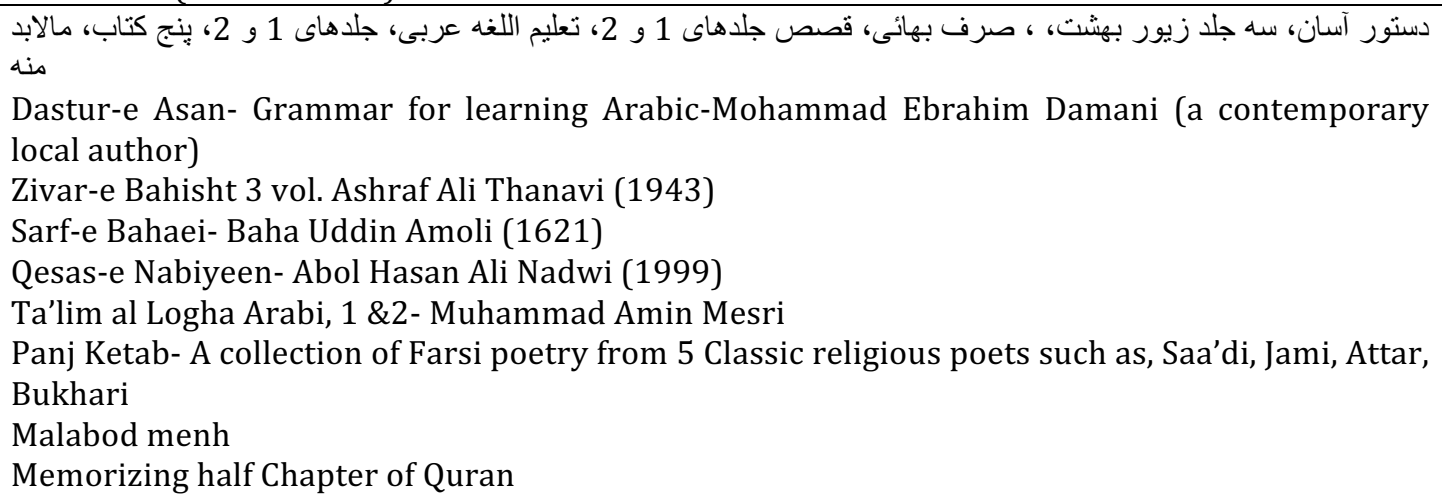 \\
\hline Year 2 & $\begin{array}{l}\text { نحوميير، آيات منتخبات، قصص نبيين جلد 3و 4، جمال اقرآن، تعليم اللغه } 3 \text { و 4، ميزان الصرف، فقه ميسر (1413) } \\
\text { Nahou-Mir- Mir Shareef Ali Jarjani (19) } \\
\text { Ayat-e Montakhabat- Mohammad Ebrahim Damani } \\
\text { Qesas-e Nabiyeen-, 3\&4 } \\
\text { Jamal al-Quran- Ashraf Ali Thanavi (1943) } \\
\text { Ta'lim al-Logha Arabia } 3 \text { \&4 Muhammad Amin Mesri } \\
\text { Meezaan-as-Sarf- Siraajuddin Usman Awadhi (1357) } \\
\text { Fiqh-e Maysar (Hanafi)- Shafiq alrahman Nadwi (19?) } \\
\text { Memorizing half Chapter of Quran }\end{array}$ \\
\hline Year 3 & 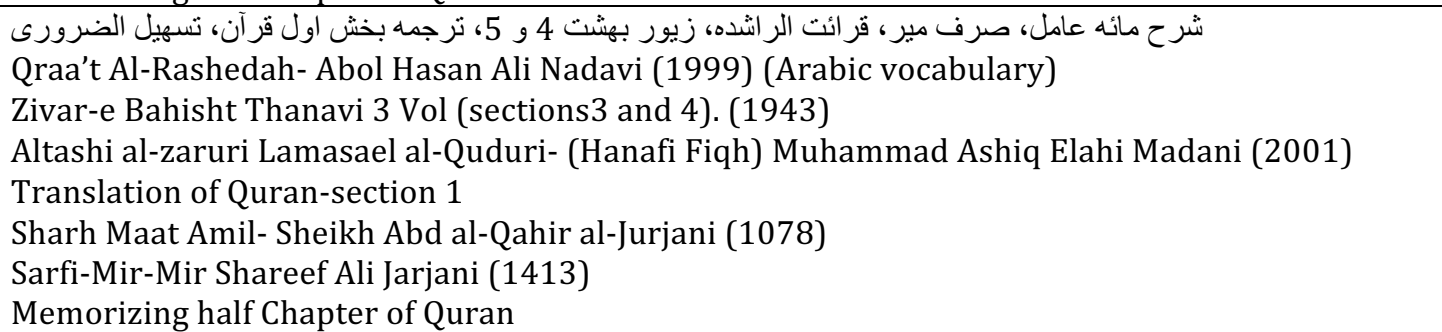 \\
\hline Year 4 & $\begin{array}{l}\text { تيسير، قدورى، ترجمه قرآن بخش دوم، خلفاى راشدين، نحو الواضح، قصص النبيين جلد 5، رياض الصالحين (1037) } \\
\text { Mukhtasar al-Quduri- Abu Hasan Ahmed Quduri (19) } 1935 \text {-) } \\
\text { Taisir (Mostaleh al-Hadith-Mahmud Ibn Ahmad al-Tahan (borne } \\
\text { Translation of Quran section2 } \\
\text { Kholafay-e Rashedin- Abd-al-Shakur Laknawi (1961) } \\
\text { An Nahw al-Vazeh-Ali al-Jarim and Mostafa Ameen } \\
\text { Qesas al-Nabyyin-4 Abol Hasan Ali Nadwi (1999) } \\
\text { Ryadh as-Salehin- Abu Zakaria Yahya bin Sharaf al-Nawawi (1277) } \\
\text { Memorizing half Chapter of Quran (in total they memorise } 2 \text { chapters by the end of year 4) }\end{array}$ \\
\hline Year 5 & $\begin{array}{l}\text { آثار اسنن اصول الثاشى ترجمه بخش } 3 \text { هدايه فى النحو، هدايه فى الدرايه جلد اول، مصطلح الحديث، عقيده الطحاويه، } \\
\text { Hedayat-fi alnahva } \\
\text { Hedayah fi aldarayah vol } 1 \text { - Burhan al-Din Abi al HasanAl-Farghani (1197) } \\
\text { Mostaleh al-Hadith-Mahmud Ibn Ahmad al-Tahan (borne 1935 -) } \\
\text { Asar al-Sonan- Mohammad Ibn Ali an Nimaway } \\
\text { Aqeedat Attahaawiyeh- Abu Jafar Ahmed Tahaavi (933) } \\
\text { Translation of Quran- part } 3 \\
\text { Assowl Ash-Shaashi-Nizamuldeen Shaashei Qandi (1359) }\end{array}$ \\
\hline Year 6 & $\begin{array}{l}\text { هدايه فى الدر ايه جلد 2، مشكات، ترجمه قرآن بخش آخر ، منتخبات، حصون حميديه، سر اج فى اميراث، بلاغه (1197 } \\
\text { Hedayah fi aldarayah vol 2- Burhan al-Din Abi al HasanAl-Farghani } \\
\text { Translation of the last section of Quran } \\
\text { Montakhabat- } \\
\text { Hosun-e Hamidyah- Sheikh Husain Ibn Mohammad Trablosi } \\
\text { Siraj fi al-Mirath- Shaykh Siraj Muhammed bin Abdur Rashid al-Sajawandi (1203) } \\
\text { Drus al-Balagha- Hafni Nasef, Mohammad Dyab, Sultan Mohammad, Mostafa Tamum } \\
\text { Mishkaat Ul Musaabih-Wali Uddin Khateeb Iraqi (1339) }\end{array}$ \\
\hline
\end{tabular}




\begin{tabular}{|l|l|}
\hline Year 7 & سنن ابى داوود دو جلد، صحح مسلم، صحح بخارى تفسير جلالين، معانى الاثار، جامع ترمذى 2 جلد (1459) \\
Tafseer Jalaaleen- Jallal Uddin mahali (1505) \\
Tafsse- Jalaal ulddin Seyuti (1505) \\
Maani Ul-Aasaar-Abu Jafar Ahmed Tahaavi (933) \\
Sahih Bukhari- Muhammad Bin Ismaeel Bukhari (870) \\
Sahih Muslim- Abu ulhusain Muslim Neeshapuri (875) \\
Sunin Abu Dawood-Abu Dawwod Sulaiman Sajastani (889) \\
(2 Vol) \\
Jaama Tirmizi- Muhammad Bin Isa Tirmizi (892) (2 vol) \\
\hline
\end{tabular}

\section{Appendix- 3}

Table- 3: Number of women graduated from the "Village Madrasa"

\begin{tabular}{|l|l|}
\hline Year & No. of talibahs graduated \\
\hline $2001(1423 \mathrm{Hq})$ & 29 \\
\hline $2002(1424 \mathrm{hq})$ & 20 \\
\hline $2003(1425 \mathrm{hq})$ & 13 \\
\hline $2004(1426 \mathrm{hq})$ & 10 \\
\hline $2005(1427 \mathrm{hq})$ & 10 \\
\hline $2006(1428 \mathrm{hq})$ & 9 \\
\hline $2007(1429 \mathrm{hq})$ & 6 \\
\hline $2008(1429 \mathrm{hq})$ & 6 \\
\hline $2009(1430 \mathrm{hq})$ & 6 \\
\hline $2010(1431 \mathrm{hq})(1390 \mathrm{hs})$ & 3 \\
\hline $2011(1432 \mathrm{hq})(1391 \mathrm{hs})$ & 4 \\
\hline $2012(1433)(1392 \mathrm{hs})$ & Not available \\
\hline $2013(1434 \mathrm{hq})(1393 \mathrm{hs})$ & Not available \\
\hline $2014-2015(1435 \mathrm{hq})((1394 \mathrm{hs})$ & Not available \\
\hline $\begin{array}{l}\text { 2015-2016 (1436-1437hq) (1394- } \\
1395 \mathrm{hs})\end{array}$ & $\begin{array}{l}9 \text { [7 Hafiz women and } 50 \text { men, of whom } 1 \text { had been killed in an } \\
\text { accident before graduation, and 13 men hafiz] }\end{array}$ \\
\hline $2016-2017(1395-1396 \mathrm{hs})$ & $\begin{array}{l}7 \text { [3 women hafiz, and } 48 \text { men graduate, 23 men hafiz, 23 men } \\
\text { specialist, 6 in hadith and 17 in Fiqh and some of them were } \\
\text { from last year] }\end{array}$ \\
\hline
\end{tabular}

Sources: The data have been collected by the author through interviews and semi structuredquestionnaires. The figures at least from 2008 do not include hafizes who memorise Quran by heart, but the figure for the female hafiz was only 2 in 2010.hq is for lunar Islamic year and hs is for solar Islamic year used in Iran. 


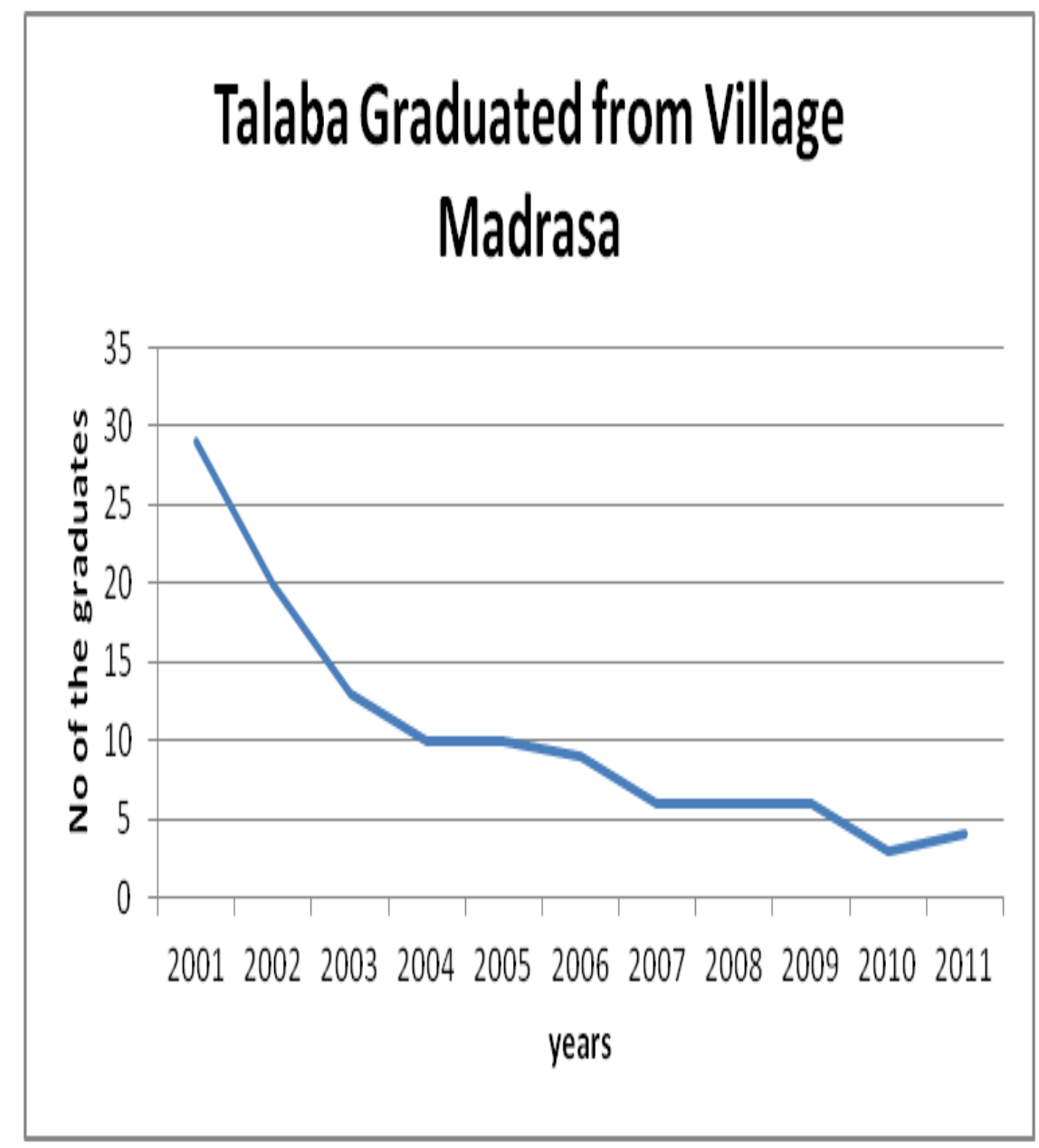

Figure 1: female Talibahs Graduated from "Village Madrasa"

\section{BIBLIOGRAPHY}

Alam, F. (2010) "A Study of Girls' Madrasas in India". Accessed on 25/11/2010.

http://www.hivos.net/content/download/31862/203381/file/Gender_Paper\%20F.\%20Alam.pdf

Aldridge, A. (2000) "The Sovereign Consumer? Religious Allegiance and Disaffiliation in Detraditionalised World", in L.J. Fran and J.K. Yaccow (eds.) Joining and Leaving Religion: 9-19. Leominster: Gracewing.

Ali, H. S. (2009) "Islam and Education: Conflicts and Conformity in Pakistan's Madrassah." Oxford: Oxford University).

Bano, M. (2007) “Beyond Politics: Reality of a Deobandi Madrasah in Pakistan”. Journal of Islamic Studies 18 (1): 43-68.

Bano, M. (2010) “Female's Madrasas in Pakistan: a Response to Modernity”. Working paper 45. Religion and Development. University of Birmingham.

Bauman, Z. (2007) "Liquid Times". Cambridge: Polity.

Beck, U. (2000) "Living Own Life in A Runaway World: Individualisation, Globalisation and Politics" in Hutton, W. and A. Giddens (eds.) On the Edge: Living with Global Capitalism. London: Jonathan Cape.

Beyer, F. P. (1990) "Privatization and the Public Influence of Religion in Global Society" in M. Featherstone (ed.) Global Culture: Nationalism, Globalization and Modernity. 373-395. London: Sage publications.

Bourdieu, P. (1990) The Logic of Practice. Cambridge: Polity.

Brannen, J. A and Nilson, A (2005) "Individualisation, Choice and Structure: A Discussion of Current Trends in Sociological Analysis", The Sociological Review 53 (3): 412-428. 
Butt, R (2009) “All-female's madrasas expanding rapidly in Pakistan”. Accessed on 12/11/2010.

http://southasia.oneworld.net/todaysheadlines/all-female-madrasas-expanding-rapidly-in-pakistan

CRS (2008) "Report for Congress of January 2007". http://www.fas.org/sgp/crs/misc/RS21654.pdf

Butt, R. (2009) "All-female madrasas boom in Pakistan". Guardian.

http://www.theguardian.com/world/2009/may/14/pakistan-madrasas-islam-girls-women

Eshaa't al-Towhid (website) (2013) “Nim-nomay-e dakheli az Hawzeh Elmyyeh Eshaa't al-Towhid-e shahrestan-e Saravan (An outline of Eshaa't al-Towhid Madrasa in Saravan District), Accessed on

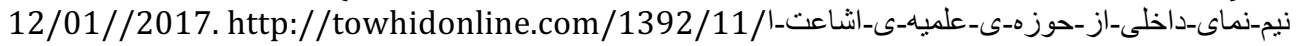

Eshaa't al-Towhid (website) (2017) “Gozareshi az hamayesh-e khatm-e Bukhari-ye Dar Ul-Ulum-e Zahedan 96 (A Report from the Celebration of the Bukhari Graduation of Dar ul-Ulum Zahedan 96)". Accessed on 12/05/2017. http://towhidonline.com/1396/02/كزارشى-از-همايش-ختم-بخارى_دار العلوم-زا/26)

Fair, C. C. (2008) “The Madrassah Challenge: Militancy and Religious Education in Pakistan”. Lahore: Vanguard Books.

Farooq, M. (2010) "Disciplining the Feminism: Girl's Madrasas Education in Pakistan". Accessed on 10/11/2010. http://www.gcu.edu.pk/FullText/our/Hist/V3N205/P64-88.pdf

Giddens, A. (1991) "Modernity and Self- Identity". Cambridge: Polity.

Hardy, P. (1972) "The Muslims of British India". Cambridge University Press: Cambridge.

Heelas, P. (1996) "Introduction: Detraditinalization and its rivals" in P. Heelas, S. Lash and P. Morris (eds.). Detraditinalization: Critical Reflections on Authority and Identity. Oxford: Blackwell.1-20.

ICG. (2005) "The State of Sectarian in Pakistan". Asia Report No 95.

http://www.crisisgroup.org/en/regions/asia/south-asia/pakistan/095-the-state-of-sectarianism-inpakistan.aspx

ICG (2009) "Pakistan: The Militant Jihadi Challenge". Asia Report No 164.

http://www.crisisgroup.org/en/regions/asia/south-asia/pakistan/164-pakistan-the-militant-jihadichallenge.aspx

ICG. (2007) “Pakistan: Karachi's Madrasas and Violent Extremism”, Asia Report No 130 - 29 March 2007. http://www.crisisgroup.org/ /media/Files/asia/southasia/pakistan/130_pakistan_karachi_s_madrasas_and_violent_extremism.ashx

Ismailzahi, A. (Moulvi Abdolhamid) "Gozaresh safar-e akhir moulana Abdolhamid be Chahbahar va jonub-e Makoran (the Report of Moulana Abdolhamid's recent Travel to Chahbahar and the South Makoran)". Accessed on 12/5/2017. http://www.sunnatnews.net/كز ارش-سفر -اخير -مو لانا_عبدالحميد-به-جاب /

Jalil, J. (2005) "Pakistan's Islamic girl schools". BBC News. http://news.bbc.co.uk/1/hi/world/south_asia/4258224.stm

Jamia Minhaj Ul Sharia Dar ul-Ulum Orangi (2010). Accessed on 10/10/2010. http://www.youtube.com/watch?v=uySwGEVMF-0

Jeffery, P., Jeffery, R., Jefferey, C. (2004) “Islamization, Gentrification and Domestication, "A Girls' Islamic Course” and Rural Muslims in Western Uttar Pradesh", Modern Asian Studies 38, 1-53.

Jeffery, P., Jeffery, R., Jefferey, C. (2006) “The First madrasa; Learned Mowlawis and the Educated Mother" in J-P Hartung and H, Reifeld (eds.) Islamic Education, Diversity and National Identity: Dini Madaris in India Post 9/11."New Delhi: Sage Publications: 227-251.

Lughod, L. A. (1998) Remaking Women: Feminism and Modernity in the Middle East, New Jersey: Princeton University Press.

Mahmood, S. (2005) The Politics of Piety: The Islamic Revival and the Feminist Subject, Princeton: Princeton University Press

Mahmood, S (2001) “Feminist Theory, Embodiment, and the Docile Agent: Some Reflections on the Egyptian Islamic Revival", Cultural Anthropology 16 (2), 202-236.

Mahmoodzahi, A. (2016) “Ddasiseh azadi-ye zan (The Conspiracy of Women's Freedom)”. Accessed on 15/06/2017. http://alshamsonline.com/shams-25/

Metcalf, B. D. (1982) Islamic revival in British India Deoband, 1860-1900. Oxford University Press: New Delhi. 
Metcalf, B. M. (2004) Islamic Contestations: Essays on Muslims in India and Pakistan. Oxford University Press: New Delhi.

Noraiee, H. (2008) “Change and Continuity: Power and Religion in Iranian Balochistan”, C. Jahani, A. Korn and P. Titus (Eds.) The Balocjh and Others: Linguistic, Historical and Socio-Political Perspectives on Pluralism in Balochistan. Wiesbaden: Reichert Verlag.

Noraiee, H. (2011), “Deobandi Female Madrasas in South Asia”. Available on Academia site. http://www.academia.edu/8736867/Deobandi_Female_Madrasas in_South_Asia.

Noraiee, H. (2015). Zaminehaye paydayesh wa roshde radicalism siasi-mazhabi wa tashanojjat-ekonuni dar Sistan and baluchistan (The Context of the Emergence and Development of Sunni Political-religious Radicalism in Sisyan and Bbaluchistan (Iran). Available on Taptan.com. http://www.taptan.com/?lang=fa.

Rashid, A. (2001) Taliban: the Story of the Afghan Warlords. Basingstoke: Pan Books.

Riesebrodt, M. (1993) Pious passion: The Emergence of Modern Fundamentalism in the United States and Iran (Tr: Don Renan). Berkeley: University of California Press.

Roul, A. (2010) “The Ghazi Brigade: Lal Masjid Episode Continues to Haunt Pakistan”. Accessed on 4/12/2010. http://counterterrorismblog.org/2010/07/the_ghazi_brigade_lal_masjid_c.php

Ruthven, M. (2007) Fundamentalism: A very Short Introduction. Oxford: Oxford University Press.

Scott, S. (2010) "Revisiting the Total Institution: Performative Regulation in the Reinventive Institution". Sociology 44 (2): 213-231.

Shams online (2016) Dowmin hamayesh moshtarak-e danesh amulkhtagy-e tollab-e Dar ul-Ulum Haqqaniyyah wa Shams ul-Ulum- e Iranshahr bargozar shod (The Second Jjoint Ceremony of Graduates of Dar ul-Ulum-e Haqqaniyyah and Shams ul_Ulum-Iranshahr was held)". Accessed on 12/7/2017 at: http://alshamsonline.com/gozaresh-2/

Sikand, Y. (2006) "The Indian Madaris and the Agenda of Reform”, Hartung, J. and Reifeld, H. (ed.) Islamic Education, Diversity and National Identity: Dini madaris in India Post 9/11. New Delhi: Sage Publications, 269-282).

The Middle East Media Research Institute (MEMRI) 1907. Who Are the Women in the Islamabad Standoff? A Look Inside the Jamia Hafsa Madarsa. Report No 369, July 10 2010. Accessed on 2/12/2010. http://www.memri.org/report/en/0/0/0/0/0/141/2282.htm

Sunni online (website) (2017) “Moa'rafi-ye Dar ul-Ulum-e Zahedan (Introduction of Zahedan Dar ul Ulum). http://sunnionline.us/farsi/daroruloom-zahedan, accessed on 12/05/2017

Veter, B. (2003) "Spiritual capital: Theorising religion with Bourdieu against Bourdieu”, Sociological Theory 21 (2): 150-174.

Winkelmann, M. J. (2005) From Behind the Curtain: A Study of a Girls' madrasa in India. Amsterdam: Amsterdam University press. Accessed on 28/11/2010. https: //open access. leidenuniv. nl/bitstream/1887/10064/1/Dissertation_Winkelmann.pdf

Wood, M. and Bunn, C. (2009) "Strategy in Religious Networks: A Bourdieuian Critique of Sociology of Spirituality", Sociology 43 (20: 288-303.

Yunus, M. (1994) Women in the Field of Education and Piety, Dewsbury: Darul Kutub. 